Folia Cardiologica 2017

\title{
Serowate włóknienie pierścienia zastawki mitralnej - groźny wygląd, łagodny charakter*
}

\section{Caseous calcification of mitral annulus: malicious look and benign character}

\author{
Katarzyna Starzyk ${ }^{1}$, Anna Kot ${ }^{1}$, Michał Spałek ${ }^{2,3}$, Beata Wożakowska-Kapłon ${ }^{1,2}$ \\ ${ }^{1}$ I Klinika Kardiologii i Elektroterapii Świętokrzyskiego Centrum Kardiologii w Kielcach \\ ${ }^{2}$ Wydział Lekarski i Nauk o Zdrowiu Uniwersytetu Jana Kochanowskiego w Kielcach \\ ${ }^{3}$ Zakład Diagnostyki Obrazowej Świętokrzyskiego Centrum Kardiologii w Kielcach
}

\section{Streszczenie}

Serowate włóknienie pierścienia zastawki mitralnej (CCMA) jest rzadkim typem zwapnienia pierścienia zastawki mitralnej. Przedstawiono przypadek 82-letniej pacjentki, hospitalizowanej z powodu objawów niewydolności serca i migotania przedsionków, z szybką częstotliwością rytmu komór 180/min. Echokardiograficznie stwierdzono owalną masę u podstawy płatka tylnego, w obrębie pierścienia zastawki mitralnej. Na podstawie diagnostyki obrazowej przeprowadzonej z zastosowaniem echokardiografii przezprzełykowej, tomografii komputerowej oraz rezonansu magnetycznego rozpoznano CCMA. Poprawę stanu ogólnego chorej z powrotem rytmu zatokowego uzyskano po wdrożeniu farmakoterapii. Pacjentkę zdyskwalifikowano z postępowania chirurgicznego, zakwalifikowano do dalszej obserwacji z okresową kontrolą echokardiograficzną.

Słowa kluczowe: serowate włóknienie, zastawka mitralna

Folia Cardiologica 2017; 12, 4: 390-393

\section{Wstęp}

Zwapnienia pierścienia zastawki mitralnej (MAC, mitral annular calcification) powstają w wyniku procesu degeneracyjnego struktur włóknistych zastawki mitralnej. Występują u 8-15\% badanych, częściej u starszych kobiet, zwłaszcza w przypadku obecności czynników zwiększających ryzyko sercowo-naczyniowe (nadciśnienie tętnicze, cukrzyca, dyslipidemia, nikotynizm), przyspieszających degenerację zastawki (nadciśnienie tętnicze, stenoza aortalna, kardiomiopatia przerostowa, wypadanie płatka zastawi mitralnej) lub osteoporozy, przewlekłej choroby nerek, schorzeń metabolicznych (np. zespół Marfana). Ich istotność kliniczna wynika ze związku z obecnością choroby wieńcowej i zwiększonym ryzykiem zgonu. Obecność MAC, ze względu na zawężenie wielkości ujścia mitralnego, może prowadzić do powstawania istotnej wady zastawki mitralnej, zaburzeń funkcji rozkurczowej lewej komory serca lub arytmii [1, 2].

\section{Opis przypadku}

Kobieta w wieku 82 lat została przyjęta do kliniki kardiologii z powodu kołatania serca oraz duszności trwających kilka godzin. W spoczynkowym zapisie elektrokardiograficznym 



Rycina 1A, B. Owalna masa u podstawy płatka tylnego w echokardiografii przezklatkowej w projekcjach przymostkowych w osi długiej (A) i krótkiej (B)

(EKG) stwierdzono migotanie przedsionków z częstotliwością rytmu komór 180/min, o czasie trwania niemożliwym do ustalenia, po raz pierwszy rozpoznane tej u chorej. Pacjentka dotychczas była leczona z powodu choroby wieńcowej i miażdżycy tętnic - wieńcowych (po zawale serca) oraz obwodowych (po udarze mózgu i endarterektomii prawej tętnicy szyjnej wewnętrznej), a także nadciśnienia tętniczego, cukrzycy typu 25 hipercholesterolemii. W terapii zastosowano $\beta$-adrenolityk, uzyskując powrót rytmu zatokowego, oraz dabigatran, zważywszy na wysokie ryzyko wystąpienia incydentu zakrzepowo-zatorowego (7 pkt. $\mathrm{CHA}_{2} \mathrm{DS}_{2} \mathrm{VAsc}$ ). Zoptymalizowano również leczenie hipotensyjne, uzyskując stabilizację stanu ogólnego pacjentki i ustąpienie objawów. W wykonanym przezklatkowym badaniu echokardiograficznym (TTE, transthoracic echocardiography) w okolicy spoidła i u podstawy płatka tylnego zastawki mitralnej uwidoczniono owalną mase, o wymiarach $30 \times 20 \times 16 \mathrm{~mm}$, centralnie hipoechogeniczną, o wyższym, typowym dla zwapnień, kontrastowaniu obwodowo (ryc. 1).

Poza opisywaną zmianą w TTE stwierdzono nieprawidłowy profil przepływu przez zastawkę mitralną (E/A 0,7) zwiększony stosunek fal E/E' i niepowiększony lewy przedsionek serca (wskaźnik masy lewego przedsionka [LAVI, left atrial volume index] $32 \mathrm{ml} / \mathrm{m}^{2}$ ). Grubość mięśnia lewej komory serca i jej kurczliwość były prawidłowe (frakcja wyrzutowa [EF, ejection fraction] 65\%), funkcja zastawek serca nie była istotnie niezaburzona, a maksymalna prędkość fali niedomykalność trójdzielnej wynosiła $2,5 \mathrm{~m} / \mathrm{s}$ (podwyższony E/E' mógł odzwierciedlać zaburzenia funkcji rozkurczowej lub też, jak uznano u omawianej pacjentki, wynikać z zaawansowanych zwapnień w pierścieniu mitralnym). W celu poszerzenia diagnostyki stwierdzonej masy wykonano przezprzełykowe badanie echokardiograficzne (TOE, transoesophageal echocardiogram), w którym potwierdzono obecność dodatkowej struktury przy pierścieniu zastawki mitralnej, wzdłuż i u podstawy płatka tylnego (ryc. 2).
Pacjentkę poddano również badaniu rezonansu magnetycznego (CMR, cardiac magnetic resonance), w którym w miejscu tylnej części pierścienia zastawki mitralnej uwidoczniono ubogosygnałową strukturę (zarówno w obrazie T1-, jak i T2-zależnym), ulegającą wzmocnieniu jedynie w części obwodowej (co sugerowało obecność zwapnień), o wymiarach $15 \times 18 \mathrm{~mm}$ i długości wzdłuż pierścienia równej $38 \mathrm{~mm}$ (ryc. 3). Z kolei w wykonanej tomografii komputerowej (CT, computed tomography) serca zmiane oceniono jako uwapnioną, nieulegającą wzmocnieniu po podaniu środka kontrastowego, co wskazywało na brak unaczynienia (ryc. 4).

Na podstawie przeprowadzonej diagnostyki rozpoznano serowate włóknienie pierścienia mitralnego. Ze względu na stabilny obraz kliniczny po zastosowaniu leczenia farmakologicznego oraz brak istotnej wady zastawki mitralnej chorą zakwalifikowano do leczenia zachowawczego i obserwacji, zalecając okresową kontrolę kardiologiczną i regularne badania echokardiograficzne.

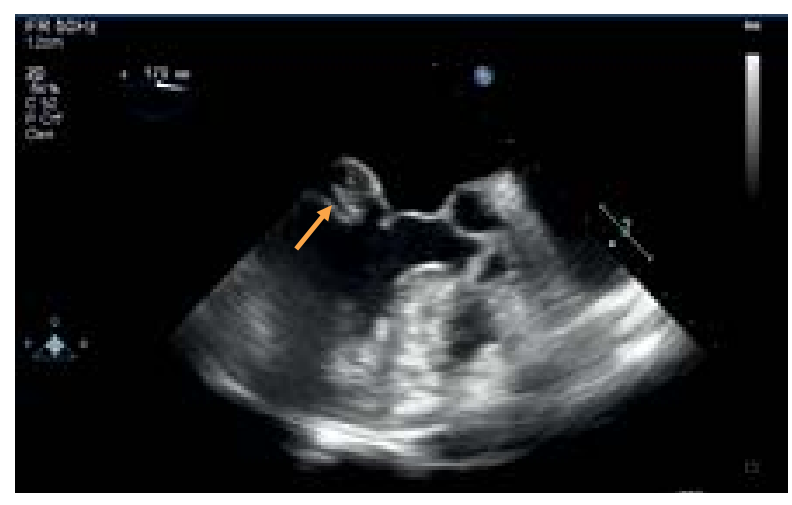

Rycina 2. Zmiana przy pierścieniu zastawki mitralnej, wzdłuż i u podstawy płatka tylnego (zmodyfikowana projekcja środkowo-przełykowa) 


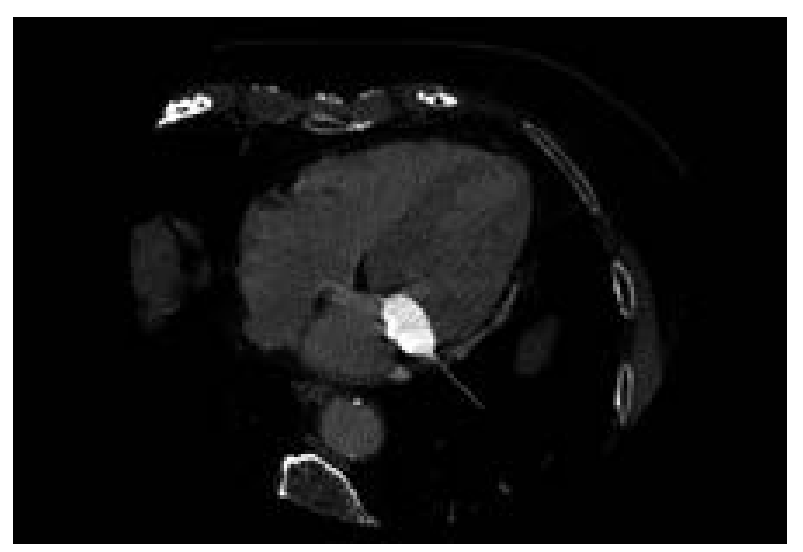

Rycina 3. Zmiana oceniana techniką tomografii komputerowej nieulegająca wzmocnieniu po podaniu kontrastu zlokalizowana wzdłuż pierścienia zastawki mitralnej

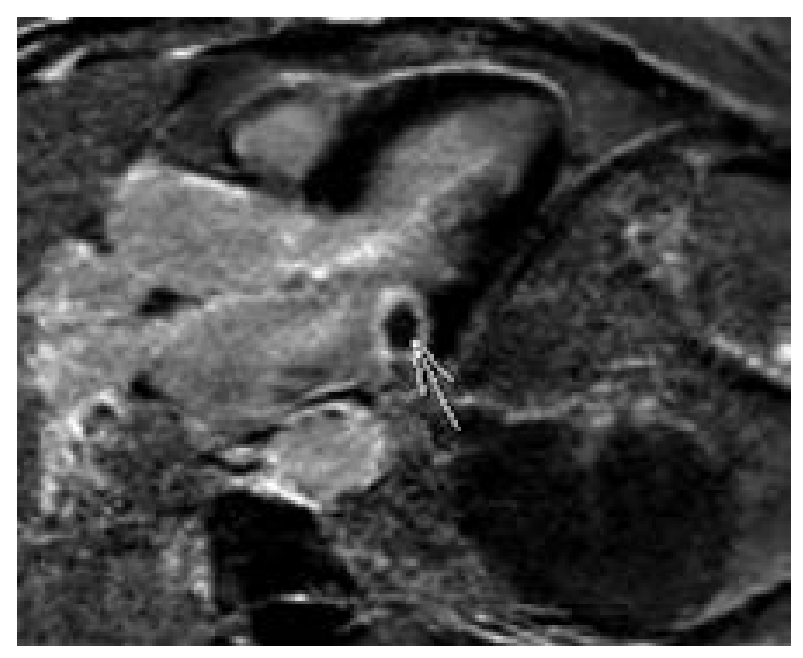

Rycina 4. Ocena metodą rezonansu magnetycznego - ubogosygnałowa zmiana, obwodowo ulegająca wzmocnieniu po podaniu kontrastu gadolinowego

charakterystyczne obwodowe umiejscowienie zwapnień, oraz wykluczyć cechy charakterystyczne dla guza nowotworowego [4-6].

Objawy CCMA zależą od wielkości zmiany. W przypadku dużych rozmiarów mogą wystąpić istotne zwężenie zastawki mitralnej, udar mózgu spowodowany pęknięciem uwapnionej otoczki i wystąpieniem zatorowości materiałem z centrum CCMA, uszkodzenie zastawki mitralnej prowadzące do niewydolności serca lub, z uwagi na bliskość węzła przedsionkowo-komorowego, zaburzenia rytmu i przewodnictwa. Zmiany o typowej charakterystyce, mniejszej wielkości, często są bezobjawowe i nie powoduja istotnych zaburzeń hemodynamicznych, dlatego nie wymagają leczenia interwencyjnego, a jedynie monitorowania i obserwacji [3-6].

$\mathrm{U}$ opisywanej pacjentki zmianę wykryto echokardiograficznie, a jej charakter potwierdzono w CT i CMR. Patomechanizm stwierdzonego migotania przedsionków, zważywszy na wspótistnienie wielu czynników ryzyka, takich jak choroba wieńcowa, nadciśnienie tętnicze i cukrzyca, najprawdopodobniej był złożony i nie wynikał wyłącznie z obecności CCMA. Ze względu na poprawę samopoczucia chorej, stabilizację stanu klinicznego oraz typowy dla CCMA obraz zarówno w echokardiografii, jak i CT i CMR, pacjentki nie zakwalifikowano do leczenia chirurgicznego. Pozostaje pod kontrolą poradni kardiologicznej, a w 3-miesięcznej obserwacji nie stwierdzono echokardiograficznie progresji i stan pacjentki pozostaje stabilny. 


\section{Abstract}

Caseous calcification of the mitral annulus (CCMA) is a rare form of mitral valve calcification. We present a 82-year-old female patient, who was hospitalized due to heart failure symptoms and atrial fibrillation with heart rate 180/min. Echocardiography revealed a round mass attached to annulus and posterior leaflet of mitral valve. Based on the multimodal diagnostics: transoesophageal echocardiography, computed tomography and magnetic resonance imaging, CCMA was diagnosed. The improvement of the general state and conversion to sinus rhythm was achieved with pharmacotherapy. The patient was excluded from surgery, and qualified for periodic echocardiographic control.

Key words: caseous calcification, mitral valve

Folia Cardiologica 2017; 12, 4: 390-393

\section{Piśmiennictwo}

1. Abramowitz Y, Kazuno Y, Chakravarty T, et al. Mitral annulus calcification. J Am Coll Cardiol. 2015; 66(17): 1934-1941, doi: 10.1016/j. jacc.2015.08.872, indexed in Pubmed: 26493666.

2. Nagueh SF, Smiseth $\mathrm{OA}$, Appleton $\mathrm{CP}$, et al. Recommendations for the evaluation of left ventricular diastolic function by Echocardiography: an update from the American Society of Echocardiography and the European Association of Cardiovascular Imaging. Eur Heart J Cardiovasc Imaging. 2016; 17(12): 1321-1360, doi: 10.1093/ehjci/jew082, indexed in Pubmed: 27422899.

3. Gorol J, Krajewski A, Tajstra M, et al. Guz serca powodujący ciężką stenozę zastawki mitralnej - opis przypadku. Folia Cardiol Excerpta. 2013; 8: 68-72.
4. Elgendy IY, Conti CR. Caseous calcification of the mitral annulus: a review. Clin Cardiol. 2013; 36(10): E27-E31, doi: 10.1002/clc.22199, indexed in Pubmed: 24038099.

5. Kurnicka K, Samul J, Piotrowska-Kownacka D, et al. Multimodal diagnosis of caseous calcification of the mitral annulus in a patient with suspected left ventricular tumor. Pol Arch Intern Med. 2017; 127(4): 281-282, doi: 10.20452/pamw.4004, indexed in Pubmed: 28436413.

6. Hamasaki A, Uchida T, Sadahiro M. Spontaneous rupture of a caseous calcification of the mitral annulus in a hemodialysis patient. J Card Surg. 2017; 32(2): 85-87, doi: 10.1111/jocs.12934, indexed in Pubmed: 28111804. 